Journal of Clinical Investigation
Vol. 42, No. 5,1963

\title{
ENDOTOXIN TOLERANCE. II. ITS OCCURRENCE IN PATIENTS WITH PYELONEPHRITIS *
}

\author{
By WILLIAM R. McCABE \\ (From the Research Laboratories, Veterans Administration West Side Hospital, and the De- \\ partment of Medicine, University of Illinois College of Medicine,
} Chicago, Ill.)

(Submitted for publication September 4, 1962; accepted January 10, 1963)

The possibility that endotoxin tolerance occurred in patients with chronic pyelonephritis was suggested from a clinical study of gram-negative bacteremia (1). Subsequent studies have demonstrated that the induction of pyelonephritis with endotoxin-producing bacteria resulted in tolerance to heterologous endotoxin in the rabbit $(2,3)$ and tended to confirm the clinical findings. Since these findings appear to offer at least a partial explanation for the relatively asymptomatic state of patients with chronic pyelonephritis, it seemed desirable to confirm them further in man. The present study was undertaken to compare the febrile response of subjects with chronic pyelonephritis and age-matched, uninfected control subjects to intravenous Salmonella typhosa vaccine. In addition, peripheral blood leukocyte counts, timed leukocyte excretion in the urine, and plasma 17-hydroxycorticosteroid (17-OHCS) levels were measured before and after pyrogen challenge to assess the effects of endotoxin tolerance on these parameters.

\section{MATERIALS AND METHODS}

Subjects. The subjects in this study were 26 adult males ranging in age from 27 to 72 years. Clinical data pertaining to these patients are shown in Table I. A variety of medical conditions was present, but no subjects were included who had diseases previously recognized to alter the febrile response to pyrogens (4-7). Twelve subjects without renal infection, hospitalized for a variety of reasons, were selected as controls. One additional control subject had chronic pyelonephritis with Streptococcus faecalis and was intentionally selected as an example of pyelonephritis due to nonendotoxin-producing species of bacteria. Thirteen patients had active urinary tract infections with gram-negative bacteria as evidence by "pale cell" pyruria and bacteriuria in ex-

* Presented in part at the 34th Annual Meeting of the Central Society for Clinical Research, November 3, 1961, Chicago, Ill. This work was done during the tenure of the VA Clinical Investigatorship. cess of $10^{5}$ bacteria per $\mathrm{ml}$ of urine in multiple urine specimens. All were adjudged to have pyelonephritis, although four of the patients are listed as having asymptomatic bacteriuria only because of the absence of symptoms at the time of examination and for identification. Three of these patients had abnormalities demonstrated by intravenous pyelography, consisting of varying degrees of calyceal dilatation or calyectasis, compatible with a diagnosis of pyelonephritis. The fourth patient (H.L.) died several months later of unrelated causes, and both gross and histologic evidence of unilateral pyelonephritis was observed at necropsy. The nine patients listed as having chronic pyelonephritis had experienced recurrent symptomatic attacks of pyelonephritis, and all had had either persistent or intermittent bacteriuria documented for at least one year. These nine patients had received 33 recorded courses of antimicrobial therapy during hospitalizations prior to the study. Intravenous pyelograms in eight of these patients demonstrated abnormalities of the renal collecting system attributable to pyelonephritis. Renal biopsy had been performed in one patient (E.M.) and revealed active pyelonephritis. Additional renal biopsies were not performed because of the typical histories and urinary findings and because previous studies in this center have demonstrated almost uniform occurrence of biopsy evidence of pyelonephritis in symptomatic patients with pyuria and bacteriuria (8).

All subjects were ambulatory and none had blood urea nitrogen concentrations in excess of $25 \mathrm{mg}$ per $100 \mathrm{ml}$. At least two and usually three urine specimens were obtained from each subject prior to pyrogen challenge to insure their accuracy. The number of bacteria present in the urine were quantitated and identified by standard methods (9-11).

Pyrogen challenge. All pyrogen studies were begun at 8:00 a.m. No antipyretic agents were administered on the day of pyrogen challenge or the preceding day, and no patient received antibiotics for 2 weeks prior to testing. Temperatures were determined rectally with the thermometer being kept in place for 5 minutes and with one of the ward personnel in attendance. After basal temperatures were recorded at 8:00, 9:00, and 10:00 a.m., $0.1 \mathrm{ml}$ of typhoid-paratyphoid vaccine $\left(10^{7}\right.$ phenol-killed bacteria) ${ }^{1}$ was administered intravenously at 10:00 a.m. Temperatures were obtained every $30 \mathrm{~min}$ -

${ }^{1}$ Lederle Laboratories, American Cyanamid Co., New York, N. Y. 
TABLE I

Clinical and laboratory data on patients with pyelonephritis and control patients

\begin{tabular}{|c|c|c|c|c|c|}
\hline Patient & Age & Diagnosis & Urine culture & $\begin{array}{c}\text { Initial } \\
\text { temperature }\end{array}$ & $\begin{array}{l}\text { Maximal } \\
\text { temperature } \\
\text { rise }\end{array}$ \\
\hline & \multicolumn{3}{|c|}{ Patients with pyelonephritis } & Degrees $F$ & Degrees $F$ \\
\hline 1. H.L. & 29 & $\begin{array}{l}\text { Rheumatoid arthritis; asympto- } \\
\text { matic bacteriuria }\end{array}$ & $>10^{6}$ E. coli & 98.6 & 1.0 \\
\hline 2. E.M. & 33 & Chronic pyelonephritis & $\begin{array}{l}>10^{7} \text { Klebsiella-Aero- } \\
\text { bacter sp. }\end{array}$ & 99.4 & 0.6 \\
\hline 3. L.W. & 42 & $\begin{array}{l}\text { Acute alcoholism; asymptomatic } \\
\text { bacteriuria }\end{array}$ & $>10^{7}$ E. coli & 100.0 & 1.2 \\
\hline 4. W.G. & 44 & $\begin{array}{l}\text { Benign prostatic hypertrophy; } \\
\text { asymptomatic bacteriuria }\end{array}$ & $\begin{array}{l}10^{6} \text { Klebsiella-Aero- } \\
\text { bacter sp. }\end{array}$ & 99.2 & 1.0 \\
\hline 5. R.C. & 45 & $\begin{array}{l}\text { Hypertension; chronic } \\
\text { pyelonephritis }\end{array}$ & $\begin{array}{l}8 \times 10^{6} \text { Klebsiella- } \\
\text { Aerobacter sp. }\end{array}$ & 98.6 & 2.4 \\
\hline 6. C.H. & 62 & $\begin{array}{l}\text { Bronchogenic carcinoma; chronic } \\
\text { pyelonephritis. }\end{array}$ & $\begin{array}{l}10^{5} \text { Klebsiella-Aero- } \\
\quad \text { bacter sp. }\end{array}$ & 100.2 & 2.0 \\
\hline 7. J.P. & 63 & Chronic pyelonephritis & $\begin{array}{l}>10^{6} \text { Klebsiella-Aero- } \\
\text { bacter sp. }\end{array}$ & 99.2 & 1.0 \\
\hline 8. J.S. & 64 & $\begin{array}{l}\text { Duodenal ulcer; renal calculi; } \\
\text { chronic pyelonephritis }\end{array}$ & $\begin{array}{l}>10^{6} \text { Pseudomonas } \\
\text { aeruginosa }\end{array}$ & 99.0 & 2.0 \\
\hline 9. J.H. & 65 & $\begin{array}{l}\text { Hypertension; congestive failure; } \\
\text { chronic pyelonephritis }\end{array}$ & $10^{6}$ E. coli & 98.6 & 2.6 \\
\hline 10. J.A. & 65 & $\begin{array}{l}\text { Diabetes; benign prostatic hyper- } \\
\text { trophy; asymptomatic } \\
\text { bacteriuria }\end{array}$ & $\begin{array}{l}10^{5} \text { Klebsiella-Aero- } \\
\quad \text { bacter sp. }\end{array}$ & 97.4 & 1.8 \\
\hline 11. E.H. & 70 & $\begin{array}{l}\text { Multiple sclerosis; chronic } \\
\text { pyelonephritis }\end{array}$ & $>10^{6}$ Proteus mirabilis & 99.4 & 2.2 \\
\hline 12. H.K. & 70 & $\begin{array}{l}\text { Benign prostatic hypertrophy; } \\
\text { chronic pyelonephritis }\end{array}$ & $\begin{array}{l}10^{7} \text { Klebsiella-Aero- } \\
\quad \text { bacter sp. }\end{array}$ & 98.8 & 1.6 \\
\hline & 72 & $\begin{array}{l}\text { Benign prostatic hypertrophy; } \\
\text { chronic pyelonephritis }\end{array}$ & $10^{6}$ E. coli & 99.0 & 3.0 \\
\hline Mean & $56 \pm 15$ & & & $99.0 \pm 0.7$ & $1.73 \pm 0.71$ \\
\hline \multicolumn{6}{|c|}{ Control patients } \\
\hline 1. J.S. & 27 & Secondary syphilis & 0 & 98.8 & 1.6 \\
\hline 2. M.G. & 39 & Hypertension & 0 & 97.9 & 2.5 \\
\hline 3. J.F. & 42 & Pulmonary blastomycosis & 0 & 99.9 & 2.0 \\
\hline 4. R.K. & 46 & Hypertension & 0 & 98.0 & 1.6 \\
\hline 5. F.B. & 47 & Duodenal ulcer & 0 & 99.6 & 3.0 \\
\hline 6. W.B. & 57 & $\begin{array}{l}\text { Hypertension; bronchogenic } \\
\text { carcinoma }\end{array}$ & 0 & 98.0 & 2.4 \\
\hline 7. J.C. & 62 & $\begin{array}{l}\text { Hypertension; bronchogenic } \\
\text { carcinoma }\end{array}$ & 0 & 98.0 & 2.0 \\
\hline 8. S.S. & 65 & $\begin{array}{l}\text { Hypertension; chronic pyelo- } \\
\text { nephritis }\end{array}$ & $2 \times 10^{6}$ S. faecalis & 98.8 & 4.0 \\
\hline 9. F.S. & 66 & Syncope, etiology undetermined & 0 & 99.0 & 3.0 \\
\hline 10. H.B. & 66 & Inguinal hernia; hypertension & 0 & 99.6 & 3.8 \\
\hline 11. J.H. & 67 & Chronic pancreatitis & 0 & 97.8 & 2.4 \\
\hline 12. A.O. & 68 & Hypertension; congestive failure & 0 & 98.2 & 3.8 \\
\hline 13. E.L. & 70 & $\begin{array}{l}\text { Duodenal ulcer; rheumatoid } \\
\text { arthritis }\end{array}$ & 0 & 98.9 & 2.5 \\
\hline Mean & $56 \pm 14$ & & & $98.6 \pm 0.61$ & $2.66 \pm 0.81$ \\
\hline
\end{tabular}




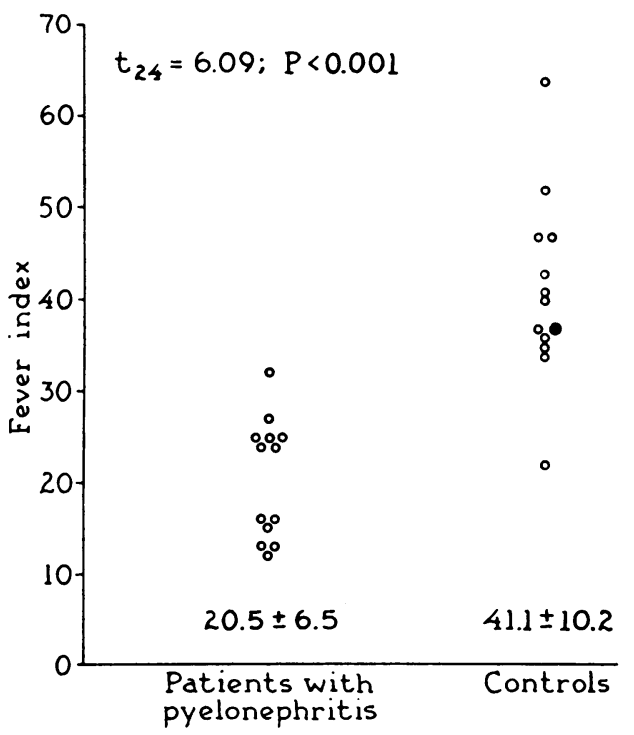

Fig. 1. Fever indexes in subjects with pyeloNEPHRITIS AND CONTROL SUBJECTS AFTER 0.1 ML OF TYPHOID VACCINE ( $10^{7}$ BACTERIA).

utes for 4 hours and hourly for an additional 4 hours. None of the patients' temperatures varied more than $0.5^{\circ}$ $\mathrm{F}$ during the initial observation period. The last control temperature (10:00 a.m.) was used as the base-line temperature. Temperatures were recorded on $1.0 \mathrm{~cm}$ graph paper with each centimeter representing $0.5^{\circ} \mathrm{F}$ or 30 minutes. The fever curve was closed by dropping a perpendicular to the base line when the temperature had not returned to control levels within 8 hours. The area enclosed by the fever curve was measured by a planimeter. Each unit on the vernier was termed a fever unit (F.U.), and the number of units representing the area above the base line was recorded as the fever index.

Blood specimens were obtained for total leukocyte and differential leukocyte counts immediately preceding and 2 and 4 hours after endotoxin administration. Standard technics were used for the enumeration of leukocytes and differential counts (12). Counts were performed in duplicate and agreed within $5 \%$.

Urinary leukocyte excretion. Timed urinary leukocyte excretion was determined by a modification of the method of Houghton and Pears (13). All urine was collected for the 3-hour periods preceding and following the injection of typhoid vaccine. Urine was obtained from an indwelling catheter in the four patients in whom residual urine and prostatic hypertrophy had been demonstrated, but voided specimens were collected from the other subjects. Urine volumes were recorded and 10-ml samples were spun at $2,000 \mathrm{rpm}$. A $9.1-\mathrm{ml}$ volume of the supernatant fluid was discarded, and $0.1 \mathrm{ml}$ of crystal violetsafranin supravital stain (14) was added to facilitate cellular identification. The remaining supernatant fluid, sediment, and stain were carefully mixed with a Pasteur pipette and added to a Spencer counting chamber. The number of leukocytes within $0.9 \mathrm{~mm}^{3}$ were counted, and epithelial cells were disregarded. The percentage of "pale staining" and "dark staining" leukocytes was determined (15). All counts were performed in triplicate.

17-OHCS response. Forty $\mathrm{ml}$ of venous blood was collected in heparinized syringes immediately before and 4 hours after the administration of typhoid vaccine. The blood was centrifuged and the plasma separated and frozen within 1 hour. Plasma 17-OHCS levels were determined on duplicate specimens by the method of Peterson and associates (16).

\section{RESULTS}

Data pertaining to the age, underlying diseases, results of urine cultures, control temperatures, and maximal temperature rise observed after intravenous challenge with typhoid vaccine of each subject is shown in Table I. None of the patients had received antimicrobial therapy recently. Four of the patients (E.M., C.H., H.K., and J.B.) had been admitted with febrile episodes of pyelonephritis. These episodes responded well to symptomatic therapy, and these patients were not treated with antibiotics until after the completion of pyrogen challenge. None of the patients in either group had had rectal temperatures exceeding $100^{\circ}$ $\mathrm{F}$ for 48 hours prior to the morning of the study, but two did have basal rectal temperatures of $100.0^{\circ} \mathrm{F}$ and $100.2^{\circ} \mathrm{F}$, respectively, on the morning of the study. The remaining subjects all had temperatures of less than $100.0^{\circ} \mathrm{F}$. The mean prechallenge temperature, $99.0 \pm 0.7^{\circ} \mathrm{F}$, of subjects with pyelonephritis did not differ significantly from the mean reading, $98.6 \pm 0.61^{\circ} \mathrm{F}$, observed in the control subjects. Only four of the 13 subjects with pyelonephritis had maximal temperature elevations of more than $2.0^{\circ}$ after the administration of pyrogen, while nine of the 13 control subjects had a rise of greater than $2.0^{\circ}$. The mean maximal temperature elevation after typhoid vaccine in the controls $\left(2.66 \pm 0.81^{\circ} \mathrm{F}\right)$ was significantly greater $\left(t_{24}=3.11 ; \mathrm{p}<.01\right)$ than the mean maximal elevation $(1.73 \pm 0.71)$ in patients with pyelonephritis.

The measurement of both the magnitude and duration of the fever, fever index, provides a more accurate assessment of the febrile response to endotoxin than either of these parameters alone (17, 18). The fever indexes of both groups of subjects are shown in Figure 1. The fever indexes of the subjects with pyelonephritis ranged from 12 
to 32 F.U., while control subjects had fever indexes ranging from 21 to 64 F.U. Only one of the patients with pyelonephritis (R.C.) had a fever index of more than 30 F.U., and only one of the controls (J.S.) had a fever index of less than 30 F.U. The fever index of the subject with enterococcal pyelonephritis is depicted by the solid circled dot. The mean fever index of the controls $(41 \pm 10.2$ F.U. $)$ was significantly greater $\left(t_{24}=\right.$ $6.09 ; \mathrm{p}<.001)$ than the mean fever index of subjects with pyelonephritis (20.5 \pm 6.5 F.U.).

Differences in the fever indexes of both groups were even more striking when the febrile response was correlated with the patient's age. The fever index for each subject in both groups is plotted against his age in Figure 2 and regression lines, $\pm 1 \mathrm{SD}$, are shown for both controls $(\mathrm{Y}=8.01+$ $.594 \mathrm{X})$ and subjects with pyelonephritis ( $\mathrm{Y}=4.5$ $+.302 \mathrm{X})$. Both the controls $\left(\mathrm{r}_{11}=.801 ; \mathrm{p}<.01\right)$ and pyelonephritics $\left(r_{11}=.710 ; p<.01\right)$ demonstrated a significant correlation between increasing age and enhanced responsiveness to the pyrogenic effect of endotoxin.

Mean total polymorphonuclear leukocyte counts, $\pm 1 \mathrm{SD}$, obtained from both groups before and 2 and 4 hours after typhoid vaccine are shown in Figure 3. Considerable variation of counts occurred among individuals in both groups. Although the controls exhibited a mean increase in total polymorphonuclear leukocyte count of 3,700

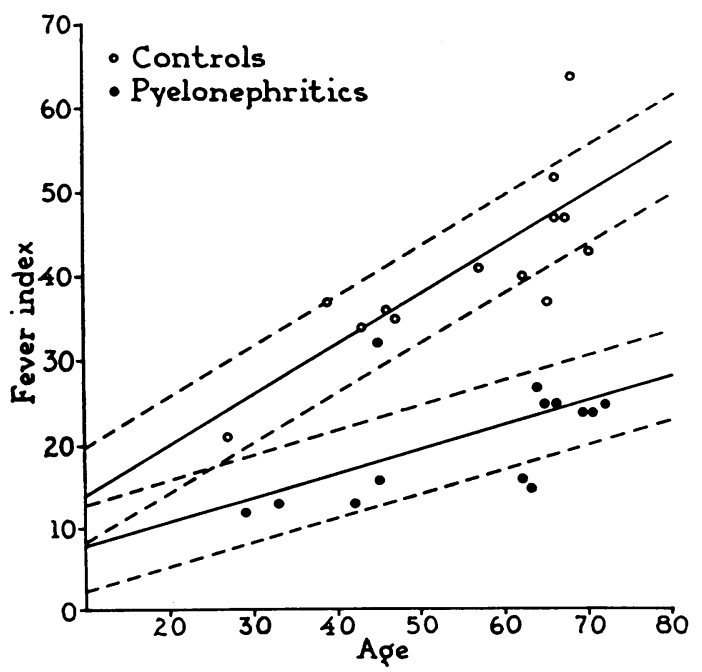

Fig. 2. Febrile Response to typhoid vaccine by AGE IN CONTROL SUBJECTS AND PATIENTS WITH PYELONEPHRITIS.

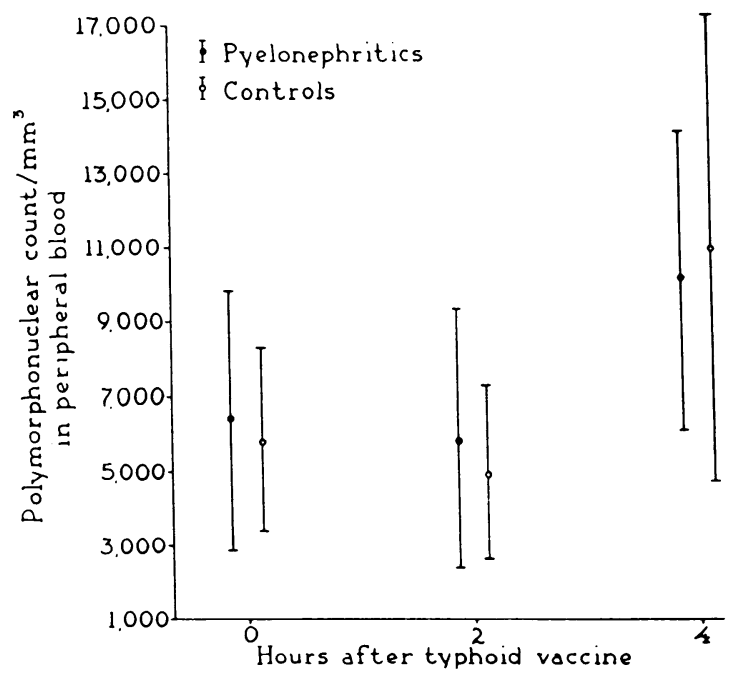

Fig. 3. PERIPHERAL BLOOD TOTAL POLYMORPHONUCleAR LEUKOCYTE COUNTS BEFORE AND AFTER ENDOTOXIN CHALLENGE.

per $\mathrm{mm}^{3} 4$ hours after endotoxin in comparison with a rise of 2,500 per $\mathrm{mm}^{3}$ in pyelonephritics, this difference was not statistically significant. The decrease in polymorphonuclear leukocytes observed 2 hours after challenge also was similar in both groups.

Timed leukocyte excretion rates before and after the administration of typhoid vaccine were determined for 12 subjects with pyelonephritis and 12 control subjects. Counts performed in triplicate varied $10 \%$ or less. The excretion rates of leukocytes for both study periods are shown in Table II. Patients with pyelonephritis all had excretion rates of $5 \times 10^{5}$ leukocytes per hour or greater, while only one of the controls, the patient with enterococcal pyelonephritis. had initial excretion rates exceeding $2 \times 10^{5}$ cells per hour. Even including the patient with enterococcal pyelonephritis, only six of the 13 patients with pyelonephritis had an increase in leukocyte excretion in the urine of $75 \%$ or greater after endotoxin. Five of 11 patients without pyelonephritis of any type also had a $75 \%$ or greater increase in urinary leukocyte excretion after typhoid vaccine. Fifty to eighty per cent of the leukocytes in the urine of patients with pyelonephritis were of the "pale staining" variety, and no significant change in their frequency was observed after the injection of typhoid vaccine. The leukocytes excreted by controls were almost exclusively "dark staining." and their rela- 
TABLE II

Changes in urinary leukocyte excretion and plasma corticosteroid levels after endotoxin

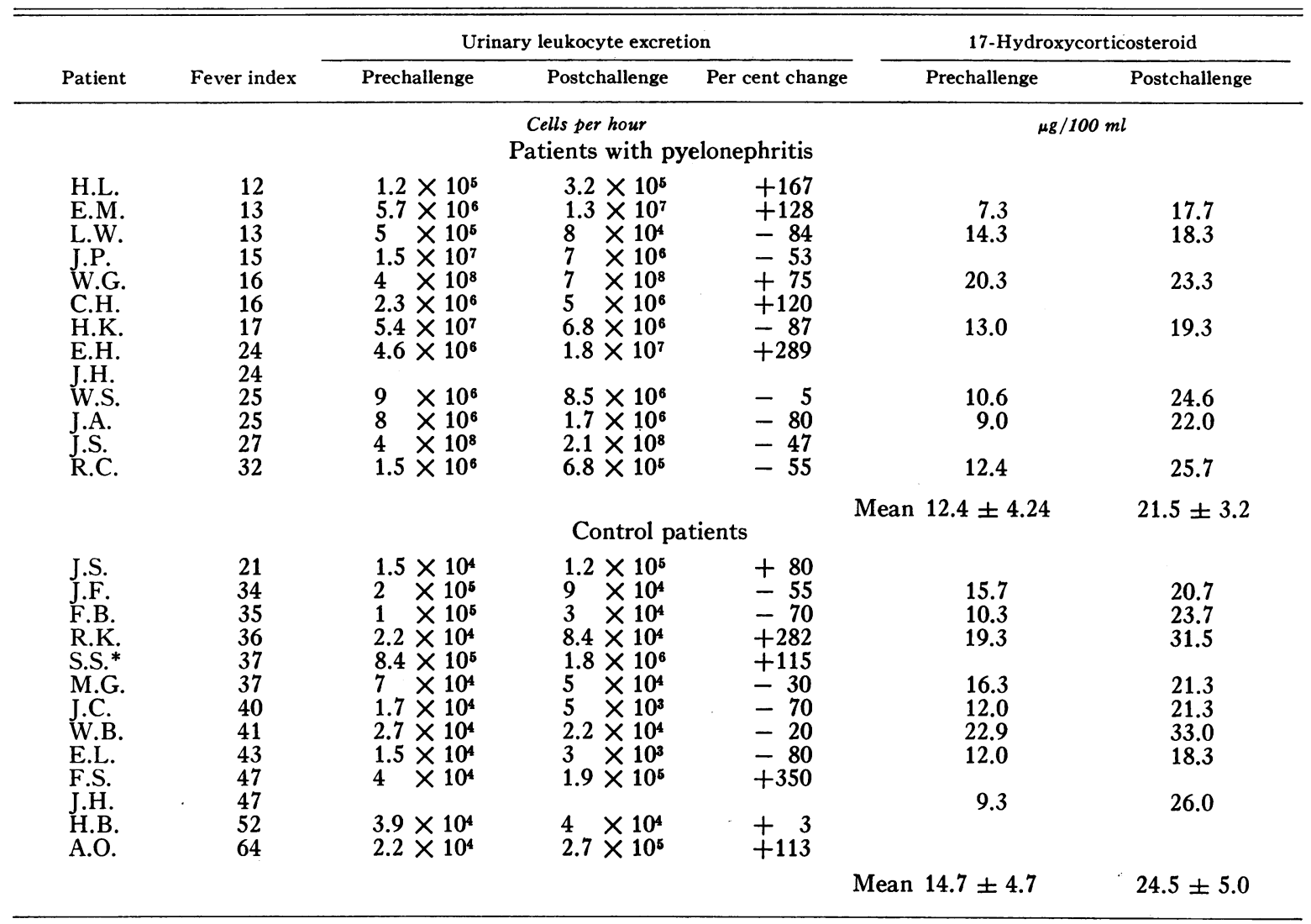

* Streptococcus faecalis pyelonephritis.

tive frequency also was unaltered by endotoxin administration.

Plasma 17-OHCS levels were measured immediately before and 4 hours after the injection of typhoid vaccine in seven subjects with pyelonephritis and in eight control subjects. These values also are given in Table II. Prechallenge 17OHCS levels were similar in both groups of patients, and similar rises occurred in both after endotoxin challenge.

No apparent relationship was observed between the degree of febrile response, the magnitude of the rise in plasma 17-OHCS, and changes in urinary leukocyte excretion in patients in either group.

\section{DISCUSSION}

The above studies describe two factors influencing the response of humans to bacterial endotoxin that had not been recognized prior to this study.
Neither the occurrence of endotoxin tolerance in humans with pyelonephritis nor the relationship of age to susceptibility to the pyrogenic effects of endotoxin in humans has been described previously. The demonstration of endotoxin tolerance in patients with chronic pyelonephritis confirms a clinical impression (1) gained from a study of gram-negative bacteremia. An earlier study demonstrated quite conclusively that the induction of pyelonephritis with gram-negative bacteria produced tolerance in rabbits known to respond normally to endotoxin and that the eradication of renal infection or reticuloendothelial blockade completely reversed the tolerant state (3). It was desired to confirm these observations in humans, and although it was not possible to reproduce these manipulations in the present study, it was shown that patients with chronic pyelonephritis due to gram-negative bacteria responded to a fixed dose of typhoid vaccine with significantly less fever than 
age-matched controls. Typhoid vaccine was selected as the challenging agent, since it represented an endotoxin unrelated antigenically to the bacterial species producing pyelonephritis and because of its previous use in similar studies. The dose used in this study was somewhat smaller than that used by others $(4,5)$, but was deliberately selected because of the steep dose-response relationship in man (19) and the suspicion that the degree of tolerance was not great and could be masked by a relatively large challenge dose. Even with this dose of vaccine, almost all of the controls experienced chills and complained of headache and muscular pains during the procedure.

It has long been recognized that chronic pyelonephritis may lead to serious renal damage in patients with only minimal signs and symptoms of infection $(20,21)$, and it has appeared enigmatic that the clinical course of this disease could be so benign despite persistent renal infection and tissue damage by virulent pyrogenic bacteria. The present data suggest that this relatively benign clinical course may partially result from tolerance to the effects of endotoxin in addition to the development of specific antibodies to the infecting organism $(22,23)$. The time of the onset of tolerance in pyelonephritis is uncertain, but it seems likely that the continued renal infection serves to maintain the tolerant state. The explanation for symptomatic exacerbations is not readily apparent, but may be related to a lapse of tolerance, increased bacterial multiplication, or the release of larger amounts of endotoxin than usual. Since the tolerant state is quite dose dependent, it is readily overcome by larger doses of endotoxin (17). Similarly, the development of tolerance may also explain defervescence in infections caused by gram-negative bacilli, as has been suggested by Neva and Morgan (6). More precise methods for the measurement of serum levels of endotoxin would greatly enhance understanding of the importance of endotoxin in clinical infections and the kinetics of the development of endotoxin tolerance.

Variations in the susceptibility to endotoxin of animals of different ages have been reported (24). McDonald, Solomon, and Shock also have demonstrated significantly greater decreases in renal vascular resistance in older patients after pyrogen challenge than in younger controls (25). These investigators postulated greater vascular reactivity to endotoxin in the elderly, and this increased susceptibility of older patients to endotoxin may partially explain the increased lethality of gram-negative bacteremia in the elderly (26).

The diagnostic value of an increase in the excretion of leukocytes in the urine after pyrogen challenge for the recognition of pyelonephritis has been the subject of a number of reports (27-29). The value of this test could not be confirmed, however, in the present investigation. The patients in this study were carefully selected as examples of documented chronic pyelonephritis. Although four of the patients had no symptoms at the time of examination, pyelograms and necropsy findings demonstrated that they had renal involvement in addition to bacteriuria. The latter group responded similarly to the other patients with pyelonephritis both with regard to pyrogen response and urinary leukocyte excretion. Increased leukocyte excretion was equally frequent in control subjects and in subjects with pyelonephritis, but basal urinary leukocyte excretion was considerably higher in subjects with pyelonephritis. Other investigations have demonstrated that the increased leukocyte excretion is not specific for pyelonephritis and may be observed in patients with hypertension and glomerulonephritis (28). A more recent study demonstrated that only two of 12 patients with chronic pyelonephritis responded to pyrogen challenge with a significant increase in urinary leukocyte excretion (30). Although the pyrogen used in the present study was derived from a different bacterial species than that used in the above reports, the similarity of the effects of all endotoxins (31-33) makes this an unlikely explanation for these differences.

Since pyrogen stimulation has been recommended as a method for the assessment of pituitary-adrenal function (34), it appeared important to insure that endotoxin tolerance did not lead to a diminution of 17-OHCS release. Study of plasma 17-OHCS levels before and after pyrogen administration in controls and tolerant patients failed to demonstrate significant differences between the two groups. A similar failure of tolerance to affect adrenal steroid excretion after pyrogen administration also has been demonstrated in experimental animals (35). Since tolerance has been considered to result from enhanced endotoxin clearance $(36-38)$, it was anticipated that a lesser 
rise in 17-OHCS would be observed in the subjects with pyelonephritis. Whether the failure of tolerance to affect adrenal steroid secretion represents extreme sensitivity of the pituitary to pyrogens is uncertain, but it does point out another area of uncertainty in understanding the actions of endotoxin.

\section{SUMMARY}

The febrile response to bacterial endotoxin was studied in 13 control subjects and 13 subjects with pyelonephritis. Patients with pyelonephritis exhibited significantly less fever after the administration of heterologous endotoxin than did agematched controls. In both groups of patients a distinct correlation between the patient's age and the magnitude of the febrile response was observed. No significant differences were observed in the magnitude of changes in peripheral blood leukocyte counts, plasma 17-hydroxycorticosteroid elevation, or urinary leukocyte excretion between the two groups after endotoxin administration.

\section{REFERENCES}

1. McCabe, W. R., and G. G. Jackson. Gram negative bacteremia. I. Etiology and ecology. Arch. intern. Med. 1962, 110, 847.

2. McCabe, W. R. Tolerance to bacterial endotoxin produced by proliferation of gram negative bacteria in the kidney. Proc. Soc. exp. Biol. (N. Y.) 1961, 107, 402.

3. McCabe, W. R. Endotoxin tolerance. I. Its induction by experimental pyelonephritis. J. clin. Invest. 1963, 42, 610.

4. Heyman, A., and P. B. Beeson. Influence of various disease states upon the febrile response to intravenous injection of typhoid bacterial pyrogen with particular reference to malaria and cirrhosis of the liver. J. Lab. clin. Med. 1949, 34, 1400.

5. Braude, A. I., J. Beck, and M. Zalesky. Febrile response to bacterial pyrogens in leukemia. Blood $1960,16,1279$.

6. Neva, F. A., and H. R. Morgan. Tolerance to the action of endotoxins of enteric bacilli in patients convalescent from typhoid and paratyphoid fevers. J. Lab. clin. Med. 1950, 35, 911.

7. Greisman, S. E., T. E. Woodward, R. B. Hornick, and M. J. Synder. Role of endotoxin in typhoid fever. Bull. N. Y. Acad. Med. 1961, 37, 493.

8. Jackson, G. G., K. P. Poirer, and H. G. Grieble. Concepts of pyelonephritis: experience with renal biopsies and long-term clinical observations. Ann. intern. Med. 1957, 47, 1165.
9. Marple, C. D. The frequency and character of urinary tract infections in an unselected group of women. Ann. intern. Med. 1941, 14, 2220.

10. Sanford, J. P., C. B. Favour, F. H. Mao, and J. H. Harrison. Evaluation of the "positive" urine culture: an approach to the differentiation of significant bacteria from contaminants. Amer. J. Med. 1956, 20, 88.

11. Kass, E. H. Asymptomatic infections of the urinary tract. Trans. Ass. Amer. Phycns 1956, 69, 56.

12. Kolmer, J. A., E. H. Spaulding, and H. W. Robinson. Approved Laboratory Technique, 5th ed. New York, Appleton-Century-Crofts, 1951.

13. Houghton, B. J., and M. A. Pears. Cell excretion in normal urine. Brit. med. J. 1957, 1, 622.

14. Sternheimer, R., and R. Malbin. Clinical recognition of pyelonephritis, with a new stain for urinary sediments. Amer. J. Med. 1951, 11, 312.

15. Poirer, K. P., and G. G. Jackson. Characteristics of leukocytes in the urine sediment in pyelonephritis. Amer. J. Med. 1957, 23, 579.

16. Peterson, R. E., J. B. Wyngaarden, S. L. Guerra, B. B. Brodie, and J. J. Bunim. The physiological disposition and metabolic fate of hydrocortisone in man. J. clin. Invest. 1955, 34, 1779.

17. Beeson, P. B. Tolerance to bacterial pyrogens. I. Factors influencing its development. J. exp. Med. 1947, 86, 29.

18. Wendt, F., E. S. Snell, F. Goodale, Jr., and W. I. Cranston. Measurement of the human febrile response to a bacterial pyrogen. Clin. Sci. 1956, 15, 485.

19. Keene, W. R., H. R. Silberman, and M. Landy. Observations on the pyrogenic response and its application to the bioassay of endotoxin. J. clin. Invest. 1961, 40, 295.

20. Longcope, W. T., and W. L. Winkenwerder. Clinical features of contracted kidney due to pyelonephritis. Bull. Johns Hopk. Hosp. 1933, 53, 255.

21. Weiss, S., and F. Parker, Jr. Pyelonephritis : its relation to vascular lesions and to arterial hypertension. Medicine (Baltimore) 1939, 18, 221.

22. Sanford, J. P., B. W. Hunter, and L. L. Souda. The role of immunity in the pathogenesis of experimental hematogenous pyelonephritis. J. exp. Med. 1962, 115, 383.

23. Braude, A. I., and J. Siemienski. The influence of endotoxin on resistance to infection. Bull. N. Y. Acad. Med. 1961, 37, 448.

24. Smith, R. T., and L. Thomas. Influence of age upon response to meningococcal endotoxin in rabbits. Proc. Soc. exp. Biol. (N. Y.) 1954, 86, 806.

25. McDonald, R. K., D. H. Solonion, and N. W. Shock. Aging as a factor in the renal hemodynamic changes induced by a standardized pyrogen. $\mathrm{J}$. clin. Invest. 1951, 30, 457.

26. Finland, M., W. F. Jones, Jr., and M. W. Barnes. Occurrence of serious bacterial infections since 
introduction of antibacterial agents. J. Amer. med. Ass. 1959, 170, 2188.

27. Pears, M. A., and B. J. Houghton. Response of infected urinary tract to bacterial pyrogen. Lancet 1959, 2, 1167.

28. Hutt, M. S., J. A. Chalmers, J. S. MacDonald, and H. E. de Wardener. Pyelonephritis. Observations on the relation between various diagnostic procedures. Lancet 1961, 1, 351.

29. Pigeon, G., M. Saint-Martin, and J. Genest. Response to bacterial pyrogen in the differential diagnosis of chronic urinary tract infection. Canad. med. Ass. J. 1961, 84, 360.

30. Little, P. J., and H. E. de Wardener. The use of prednisolone phosphate in the diagnosis of pyelonephritis in man. Lancet 1962, 1, 1145.

31. Bennett, I. L., Jr., and P. B. Beeson. The properties and biologic effects of bacterial pyrogens. Medicine (Baltimore) 1950, 29, 365.

32. Thomas, L. The physiological disturbances produced by endotoxins. Ann. Rev. Physiol. 1954, 16, 467.

33. Atkins, E. Pathogenesis of fever. Physiol. Rev. $1960,40,580$.
34. Farmer, T. A., Jr., S. R. Hill, Jr., J. A. Pittman, Jr., and J .W. Herod, Jr. The plasma 17-hydroxycorticosteroid response to corticotropin, SU-4885 and lipopolysaccharide pyrogen. J. clin. Endocr. 1961, 21, 433.

35. Egdahl, J. H., J. C. Melby, and W. W. Spink. Adrenal cortical and body temperature responses to repeated endotoxin administration. Proc. Soc. exp. Biol. (N. Y.) 1959, 101, 369.

36. Beeson, P. B. Tolerance to bacterial pyrogens. II. Role of the reticulo-endothelial system. J. exp. Med. 1947, 86, 39.

37. Atkins, E., and W. B. Wood, Jr. Studies on the pathogenesis of fever. I. The presence of transferable pyrogen in the blood stream following the infection of typhoid vaccine. J. exp. Med. 1955, 101, 519.

38. Carey, F. J., A. I. Braude, and M. Zalesky. Studies with radioactive endotoxin. III. The effect of tolerance on the distribution of radioactivity after intravenous injection of Escherichia coli endotoxin labeled with $\mathrm{Cr}^{51}$. J. clin. Invest. 1958, 37, 441. 